\title{
HospitalitasSebagai Upaya Mencegah Kekerasan Dalam Memelihara Kerukunan Dalam Relasi Islam Kristen Indonesia
}

Oleh

\author{
Merianti \\ Institut Agama Kristen Negeri Toraja \\ meriantiarruan@gmail.com
}

\begin{abstract}
ABSTRACK
The relationship between Islam and Christianity varies greatly from place to place. However, some are so close and some are also contradicting each other, because there are several factors that influence it so that they always blame each other on their respective religions. The relationship between Christianity and Islam is also very harmonious and harmonious, because they respect each other. In social life, it is very crowded because they do not see religion, but only a sense of brotherhood.

There are mostly places where the relationship between Islam and Christianity is mutually good, so that life in society is very harmonious. And also never have a problem just because of different religions, but instead they support one another. The relationship between the two religions is very strong because there is no problem just because of different religions but the value of the brotherhood of the two religions is very good. They do not relate or insult each other but these two religions support each other. The things we will strive to do in preventing violence in the relationship between Islam and Christianity are started by establishing good communication, respecting each other between religions.
\end{abstract}

\section{Abstrak}

Hubungan Islam dan Kristen di suatu tempat sangatlah berbeda-beda. namun ada yang begitu akrab dan ada juga yang saling bertentangan, disebabkan karena adanya beberapa faktor yang mempengaruhinya sehingga mereka selalu saling menyalahkan agama masing-masing. Hubungan antara Kristen dan islamada juga sangat rukun dan harmonis, karena mereka saling menghargai satu dengan yang lain. Dalam kehidupan bermasyarkatsangatlah solid karena mereka tidak memandang agama, tetapi hanya rasa persaudaraan. 
Ada sebagian besar tempat yang dimana hubungan antara Islam dan Kristen saling menjalin hubungan yang baik, Sehingga kehidupan di dalam masyarakat pun sangat rukun. Dan juga tidak pernah bermasalah hanya karena berbeda agama, tetapi justru saling mengsuport satu dengan yang lain. Hubungan kedua agama sangatlah kental karena tidak ada masalah hanya karena beda agama tetapi nilai persaudaraan kedua agama tersebut sangatlah bagus. Mereka tidak saling membenci atau saling menghina tetapi kedua agama ini saling mendukung. Hal-hal yang akan kita upayakan dalam mencegah terjadinya kekerasan dalam hubungan antara Islam dan Kristen yaitu dimulai dengan menjalin komunikasi yang baik, saling menghargai antar beragama.

Kata kunci: Islam Kristen Hubungan

Pendahuluan

Sebagai bangsa yang pluralistik karena ia menyimpan agar agar keberagaman dalam hal agama etnis, seni, tradisi, budaya, pandangan dan cara hidupAgama merupakan aturan atau tatacara hidup manusia dalam hubungannya dengan Tuhan dan sesamanya. Agama berfungsi sebagai pedoman hidup manusia, sehingga tercipta suatu hubungan serasi antar manusia dengan Yang Maha Esa. Penganut Kristen yang disebut dalam al-Qur'an dengan kaum Nashara (Nasrani). .melihat hal tersebut, maka semua umat beragama bertanggung jawab untuk tetap menjaga hubungan baik, sehingga tetap rukun dan harmonis. Taman dan perbedaan tersebut harus bisa dikelola dengan baik sehingga tidak menjadi sumber perselisihan, konflik dan kekerasan.Salah satu konflik yang sering terjadi adalah konflik antara umat Islam dan Kristen. Islam dan Kristen adalah 2 agama Islam memiliki akar sejarah yang saling berkaitan kedua agama ini tidak hanya berkaitan dengan sejarah tetapi juga berkaitan pada masa SAW hingga zaman sekarang ini. Benihbenih konflik antara islam Islam dan Kristen itu sudah ada sejak zaman Kolonialisme persaingan politik dan bisnis yang sering terjadi antar umat Islam dan Kristen.

Hubungan Islam dan Kristen di suatu tempat sangatlah berbeda-beda. namun ada yang begitu akrab dan ada juga yang saling bertentangan disebabkan karena adanya beberapa faktor yang mempengaruhinya sehingga mereka selalu saling menyalahkan agama masing-masing, mereka beranggapan bahwa agama kami yang benar. Dan hubungan yang baik itu tercipta dari masyarakat itu sendiri

Tujuan Dan Manfaat

Hubungan antara Islam dan Kristen dulu sampai sekang merupakan suatu hal yang baru bagi kita dimana hampir setiap permasalahan yang terjadi di Indonesia sebagian besar adalah persoalan agama. Tujuannya dimulai dari menjalin hubungan yang baik, menciptakan hubungan yang hidup rukun, saling menghargai dalam relasi antar beragama.

Manfaatnya

Bahwa dengan berkomunikasi yang baik dan saling menghargai antara islamdan Kristen maka akan terjalin hubungan yang harmonis sehingga menciptakan suasana yang rukun tanpa melihat adanya perbedaan.

Tujuan, agama dan hubungan 


\section{Pembahasan}

Dalam kenyataan di lapangan, sejak dulu sampai sekarang umat Kristen dan Islam selalu berada dalam persaingan untuk menambah jumlah pengikut. Walaupun terdapat enam agama resmi yaitu Islam, Protestan, Katolik, Hindu, Buddha, dan Kong $\mathrm{Hu} \mathrm{Cu}$. Tetapi hubungan paling panas selama ini adalah antara agama Islam dan Kristen. Penyebab rawan antara Islam dan Kristen (Protestan dan Katolik) di Indonesia adalah karena agama-agama itu merupakan agama dakwah (misioner) yang berupaya mengembangkan sayap sesuai mandate kitab suci masing-masing. Fakta terjadinya konflik bernuansa agama di Indonesia, khususnya pasca-orde baru, menegaskan bahwa perdamaian tidak jatuh begitu saja dari langit. Ia mesti di usahakan, dirawat, dan di lestarikan terusmenerus.

Hubungan Kristen-Islam di Indonesia, pada salah satu aspeknya mewarisi "beban sejarah" dan para pendahulunya yaitu para pembawa kedua agama. Islam hampir identic dengan Arab (Timur Tengah) dan Kristen dengan Barat. Oleh karena itu, konflik KristenIslam, sekalipun tidak disangkal ada aspek teologisnya, tetapi tidak pernh "telanjang" sebagai konflik teologi saja. Konflik itu lebih dominan di latar belakangi oleh pertentangan dua pola budaya. Hampir semua penilaian Islam tentang Kekristenan tidak didasarkn atas kekristenan yang lurus dan benar, tetapi atas sekte-sekte heteredoks (sesat, menyimpang). Dalam Islam, seperti di tegaskan Alquran, Allah telah "nazzala 'alaikal Kitaba bi al-haqq", ("menurunkan kepadamu, ya Muhmmad, kitab Alquran dengn kebemran”.). sedangkan dalam Kristen, Firman Allah telah: "naz-zala minas sama'I wa tajjasad bi-ruhil Quddusi wa min Maryama al-Adzra'I wa ta'anas" (turun dari surge, menjelma oleh kuasa Roh kudus, dan menjadi manusia dari perawan Maryam) .

\section{Kesimpulan}

Hubungan Islam dan Kristen di suatu tempat sangatlah berbeda-beda. namun ada yang begitu akrab dan ada juga yang saling bertentangan, disebabkan karena adanya beberapa faktor yang mempengaruhinya sehingga mereka selalu saling menyalahkan agama masing-masing. Hubungan antara Kristen dan islam adalah sangat rukun dan harmonis, karena mereka saling menghargai satu dengan yang lain. Dalam kehidupan sangatlah solid karena mereka tidak memandang agama, tetapi hanya rasa persaudaraan.

saling menjalin hubungan yang baik, Sehingga kehidupan di dalam masyarakat pun sangat rukun. tidak pernah bermasalah hanya karena berbeda agama, tetapi justru saling mengsuport satu dengan yang lain. Hubungan kedua agama sangatlah kental karena tidak ada masalah hanya karena beda agama tetapi nilai persaudaraan kedua agama tersebut sangatlah bagus. Mereka tidak saling membenci atau saling menghina tetapi kedua agama ini saling mendukung. 
